The Israeli Journal of Aquaculture - Bamidgeh, IJA_69.2017.1388, 8 pages

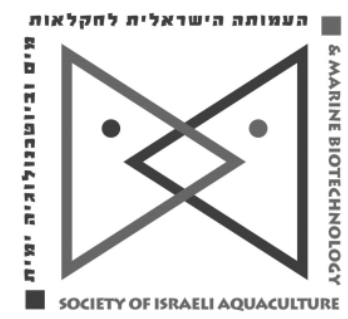

The IJA appears exclusively as a peer-reviewed on-line open-access journal at http://www.siamb.org.il. To read papers free of charge, please register online at registration form.

Sale of IJA papers is strictly forbidden.

\title{
Androgenic and Anabolic Effects of Pinus tabulaeformis Carr. Pollen in Clarias gariepinus
}

\author{
Issa Adenigba ${ }^{1,3}$, Barry Leonard M. Tumbokon², Augusto E. \\ Serrano, Jr. ${ }^{1,2} *$ \\ ${ }^{1}$ Institute of Aquaculture, College of Fisheries and Ocean Sciences, \\ University of the Philippines Visayas, Miagao 5023 Iloilo, Philippines \\ 2 National Institute of Molecular Biology and Biotechnology, University of \\ the Philippines Visayas, Miagao 5023 Iloilo, Philippines \\ ${ }^{3}$ Federal College of Fisheries and Marine Technology, Victoria Island, \\ Lagos State, Nigeria
}

Keywords: sex reversal; pine pollen; Pinus tabulaeformis; African catfish; 17- $\alpha$-methyltestosterone; testosterone

\begin{abstract}
Feeding trials were conducted to evaluate the effects of dietary pine pollen from Pinus tabulaeformis Carr. on masculinization, growth, food conversion efficiency, and survival of Clarias gariepinus. Experimental diets were prepared using a commercial feed for fry as basal diet with 5 levels of pine pollen supplementation: 0 (control, T1), 80 (T2), 160 (T3), 320 (T4), and 640 (T5) mg/kg diet; two positive control diets were also included, namely $17-\alpha$-methyltestosterone, and testosterone at $60 \mathrm{mg} / \mathrm{kg}$ diet. Two feeding trials were conducted, the first; larvae to fry for 72 days (Phase 1) and the second; fry to fingerling for an additional 45 days (Phase 2). Results showed that the percentage of males was significantly lower in the untreated diet $(50.4 \%)$ and significantly higher in all of the pine pollen groups although there was no significant difference between the pine pollen groups. The male percentage was significantly highest in the 17- $\alpha$-methyltestosterone and testosterone groups with no significant difference between the two groups. Phase 1 feeding showed that pine pollen did not affect growth, feed intake, food conversion efficiency, and survival of catfish. In Phase 2 feeding, the final average body weight (FABW), weight gain (WG), feed intake (FI), and protein efficiency ratio (PER) in all pine pollen groups similarly increased, but specific growth rate (SGR) and food conversion ratio (FCR) did not. 17- $\alpha-$ methyltestosterone treatment significantly increased WG and SGR, but enhancement was significantly inferior to the pine pollen groups $(P<0.05)$. Testosterone did not have any effect on any of the response parameters. FIs were significantly higher in the pine pollen groups than either the control, 17- $\alpha$-methyltestosterone, and testosterone groups. There was no effect on survival rate in any of the treatments All rates were statistically similar $(P>0.05)$. Conclusion: pine pollen resulted in slightly but significantly inferior androgenic effect, but anabolic effect was superior compared to both 17- $\alpha$-methyltestosterone, and testosterone. Its use for sex reversal and improved growth is recommended.
\end{abstract}

* A.E. Serrano Jr., Corresponding author. e-mail: aeserrano@up.edu.ph 


\section{Introduction}

Male African catfish, Clarias gariepinus, grow faster and reach a larger final size than females. They have better feed conversion, protein efficiency ratios, apparent net protein utilization, lower fat and energy deposition, and higher gutted weight than females (Christensen, 1981; Turan \& Akyurt, 2005). In Africa, marketable size of catfish is large $(>1 \mathrm{~kg}$ ) and buying a female catfish puts the consumer at a disadvantage since its ovaries could weigh $20 \%$ of total weight (Penman, 2016). It is therefore advantageous to consumers for fish farmers to produce all-male catfish populations.

Protocols for a list of 44 gonochore species and hermaphrodites using one of 31 steroids have been compiled (Pandian and Sheela, 1995). The induction of sex reversal involves the administration of a sex steroid (e.g. 17- $\alpha$-methyltestosterone, or testosterone) during the labile period. This treatment results in the reversion of the phenotypic expression of a genetic female into a functional male, while the genetic expression continues to be a male.

There have been objections by consumers to the use of synthetic hormones such as the 17- $\alpha$-methyltestosterone, or testosterone based on the fear that they may affect humans who consume the fish. The synthetic steroid 17- $\alpha$-methyltestosterone is commonly used to induce sex reversal in teleosts but has disadvantages of being costly and a growth suppressant (Hunter \& Donaldson, 1983). There is therefore a need to use cheaper androgens which are more acceptable to consumers and are available from natural sources such as plants.

Pine pollen, the male gamete of the pine tree, is a Chinese traditional medicinal product which has been used as a drug and as food for thousands of years. It has been used for the treatment of colds, disease of the prostate, anemia, diabetes, hypertension, asthma, and rhinitis (Lee \& Choi, 2009; Lee et al, 2009) and has the potential to retard aging and attenuate age-related diseases (Mao et al, 2012). Pine pollen is collected from Pinus massoniana Lamb., and Pinus tabulaeformis Carr. and is a stable component (Mao et al, 2012). Testosterone is present in the pollen of Pinus bungeana Zucc, Pinus silvestris L. (Šaden-Krehula et al, 1971), and Pinus tabulaeformis Carr. (Zhong-han et al, 1994). Other compounds that are derivatives of testosterone such as epitestosterone, androstenedione, dehydroepiandrosterone, and androsterone have also been detected in the pollen of Pinus silvestris (Šaden-Krehula et al, 1971) and Pinus nigra (Šaden-Krehula et al, 1979; Jones \& Roddick 1988).

Addition of dietary hormones, whether synthetic or organic, provide a great boost to profitability in aquaculture by increasing growth rates, feed intake, or food conversion efficiencies effectively shortening the production cycle. This study aims to evaluate the effect of pollen powder from Pinus tabulaeformis on the induction of sex reversal (i.e. androgenic effects) in the African Catfish, Clarias gariepinus to replace 17- $\alpha$-methyltestosterone, and testosterone, and in enhancing growth, feed intake, or food conversion efficiency or a combination of these (i.e. anabolic effects).

\section{Materials and Methods}

This study was carried out at the University of the Philippines Visayas-National Institute of Molecular Biology and Biotechnology (NIMBB) Laboratory in a recirculating system.

Artificial spawning and fertilization. Broodstocks were purchased from a commercial catfish hatchery in Zarraga, Iloilo, Philippines and transported to the university hatchery. The fish were acclimatized for 2 days before artificial spawning was conducted as described in Table 1 . At $2400 \mathrm{~h}$ females were injected intramuscularly with a commercial solution of gonadotropin and dopamine inhibitor $(0.5 \mathrm{ml} / \mathrm{kg})$ following manufacturers' instructions (Ovaprim, Syndel Lab. Ltd., USA) into the dorsal muscle above the lateral line and below the anterior part of the dorsal fin. Stripping was conducted after ovulation the following morning. Milt was collected as described by Nwadukwe et al (1993). The dry method of artificial fertilization was carried out as described by Viveen et al (1985) by mixing the milt in physiological salt solution with the ovulated eggs in a known volume of water. It was then gently stirred with plastic 
spoon and incubation was immediately carried out by spreading the fertilized eggs on previously disinfected egg mats placed inside well-aerated tanks (54 L capacity).

Table 1: Summary of spawning details for Clarias gariepinus

\begin{tabular}{lc}
\hline Weight of Female & $650 \mathrm{~g}$ \\
Weight of Male & $560 \mathrm{~g}$ \\
Temperature & $28^{\circ} \mathrm{C}$ \\
Hormone volume & $0.5 \mathrm{ml} / \mathrm{kg}$ \\
Time of Injection & $2400 \mathrm{~h}$ \\
Time of stripping & $1030 \mathrm{~h}$ \\
Fertilization rate & $70 \%$ \\
Hatching rate & $85 \%$ \\
Weight of egg after stripping & $97 \mathrm{~g}$ \\
\hline
\end{tabular}

Preparation of experimental feeds. Pine pollen powder, 17- $\alpha$-methyltestosterone and testosterone (Zhongshan Yuanhang Co., Zhejiang, China) were each dissolved in 95\% ethanol. A commercially available fry booster feed used for milkfish, tilapia, and catfish fry was used as basal diet (Santeh Feeds Corp. Quezon City, Philippines); the proximate composition of the basal diet indicated on its label is shown in Table 2 . The hormone preparations were added to the feed to produce the desired levels in each treatment and were thoroughly mixed. The mixtures were air dried at room temperature to let ethanol evaporate, oven dried at $60^{\circ} \mathrm{C}$ for $12 \mathrm{~h}$, crumbled, sieved to appropriate sizes, and stored at $4^{\circ} \mathrm{C}$ until use.

Table 2. Proximate composition of the commercial fry booster feed (Santeh Feeds Corp., Bulacan, Philippines) as written on the label

\begin{tabular}{ll}
\hline Proximate Analysis & $\%$ \\
\hline Crude Protein & 45.0 \\
Crude Fat & 8.0 \\
Crude Fibre & 5.0 \\
Ash & 16.0 \\
Moisture & 12.0 \\
NFE & 14.0 \\
\hline
\end{tabular}

Feeding, experimental design and set up. First feeding was done when hatchlings were 4 days old, upon completion of yolk absorption. The larvae were fed initially 6 times daily to satiation for the first 2 weeks, and 4 and 3 times daily for the third and subsequent weeks thereafter. Any uneaten feed, debris, and feces, were siphoned once daily. Plastic tanks were provided with continuous aeration in a recirculating system consisting of a physical filter tank (containing gravel and sand), a biological filter (containing previously disinfected oyster shells), and a sedimentation tank with fiber pad filter in a total volume of $1,400 \mathrm{~L}$ of water. Water temperature and $\mathrm{pH}$ were measured twice daily, dissolved oxygen (DO) twice weekly, and nitrite and total ammonia (using commercially available kits) once weekly.

The feed experiment was conducted in two continuous phases. In Phase 1 (i.e. larvae to fry phase), swim-up larvae (total of 3,150 and average body weight of 3.5 $\mathrm{mg}$ ) were randomly distributed into 21 plastic tanks (54-L capacity) at a density of 150 larvae/tank. Seven dietary treatments (T1-T7) were fed in 3 replicates in a completely randomized design for 72 days. T1 served as negative control containing no pine pollen; T2, T3, T4, and T5 contained $80,160,320,640 \mathrm{mg}$ of pine pollen powder/ $\mathrm{kg}$ of feed. T6 and T7 contained $60 \mathrm{mg} / \mathrm{kg}$ of $17-\alpha$-methyltestosterone and testosterone hormones, respectively, serving as positive controls. Phase 2 feeding trial (i.e. fry to fingerling phase) is the continuation of the first phase of feeding except that fish density was reduced from 150 larvae/tank to 25 fry/tank; bigger fry of uniform sizes (average body weight of $2.12 \mathrm{~g}$ ) were left in the tank for further growth trials; this reduction in density was to allow normal growth. The catfish that were removed were transferred to a new set of 21 tanks. The set up was retained (i.e. same treatments in the same tank positions) and fish continued to be fed the experimental diets for later sexing during the termination of Phase 2 feeding. The retained catfish were used for the Phase 2 feeding trial, and were fed the experimental diets for another 45 days.

In both feeding phases, the fish were fed three portions of the experimental feeds/day ad libitum. The ad libitum amount was estimated at the start and every $7^{\text {th }}$ day of the trial; the estimated amount formed the basis of feeding for the following 
week. Fish were weighed at the start, and then every 14 days; catfish were not fed on the day of weighing. The growth trials lasted for a total of 117 days and at the termination, sex of the fish was determined individually by ocular inspection of the genital papillae or by using a dissecting microscope for verification when necessary. Males exhibited elongated and pointed genital papilla while those of the female were short and round.

Estimation of response parameters. The following formulae were used to estimate the various parameters in the feeding trials: Percentage fertilization was estimated by subtracting the number of nonviable eggs (those appearing opaque and whitish) from the total number of incubated eggs after $12 \mathrm{~h}$; hatching rate was estimated after $28 \mathrm{~h}$ of egg incubation.

Fertilization rate $(\%)=100 *$ (No. of incubated eggs - No. of white eggs) $/$ No. of incubated eggs

Hatching rate $(\%)=100 *$ (No. of fertilized eggs- No. of larvae)/Number of fertilized eggs

Survival rate $(\%)=100 *$ (final count/initial count)

Growth and feed efficiency parameters were estimated using the following formulae.

$$
\text { Weight gain, WG }(\mathrm{g})=\text { FABW }- \text { IABW }
$$

Where: $F A B W=$ Final average body weight $(g)$ and

IABW = Initial average body weight $(\mathrm{g})$

Specific Growth Rate (SGR, \%/day) $=100 *($ In FABW-In IABW $) /(T 2-T 1)$

$\mathrm{FCR}=\mathrm{FI}(\mathrm{g}) / \mathrm{WG}(\mathrm{g})$

Where $\mathrm{FI}=$ total individual feed intake $(\mathrm{g})$

PER $=$ WG / (FI*feed crude protein (in decimal))

Statistical Analysis. Statistical Package for Social Sciences (SPSS) version 20 software was used to perform statistical analysis. Data from the study were presented as mean \pm standard error of the mean (SEM) and were tested for normality using Shapiro-Wilk test and variance homogeneity using Levene's test. The one-way analysis of variance (ANOVA) was used on data which passed the tests while those that did not were subjected to transformation until they passed the tests, after which one-way ANOVA tests were used at $a=0.05$. Post hoc analyses were done using Tukeys to rank the means.

\section{Results}

Masculinization. The proportion of male and female catfish in the untreated groups was $50.4 \%$ and $49.6 \%$, respectively (Table 3 ). In contrast, pine pollen-treated diets resulted in a significantly higher proportion of masculinized males (79.95 to $83.6 \%$ ) than those in the control group $(P<0.05)$; the proportion did not significantly vary between the pine pollen treated groups $(P>0.05)$. Catfish fed diets containing the sex hormones 17- $\alpha$-methyltestosterone, and testosterone, exhibited a significantly higher proportion of males ( $91.2 \%$ and $89.2 \%$, respectively) compared to the other treatment groups $(P<0.05)$.

Table 3. Proportion of male and female catfish at the end of the second phase feeding trial (117 days)

\begin{tabular}{lcc}
\hline Treatments & Males $(\%)$ & Females $(\%)$ \\
\hline T1 $($ Control $)$ & $50.4 \pm 1.3^{\mathrm{a}}$ & $49.6 \pm 1.3^{\mathrm{c}}$ \\
$\mathrm{T} 2(80 \mathrm{mg} / \mathrm{kg})$ & $82.0 \pm 1.5^{\mathrm{b}}$ & $18.0 \pm 1.5^{\mathrm{b}}$ \\
$\mathrm{T} 3(160 \mathrm{mg} / \mathrm{kg})$ & $79.9 \pm 1.7^{\mathrm{b}}$ & $20.1 \pm 1.7^{\mathrm{b}}$ \\
$\mathrm{T} 4(320 \mathrm{mg} / \mathrm{kg})$ & $83.0 \pm 1.3^{\mathrm{b}}$ & $17.0 \pm 1.3^{\mathrm{b}}$ \\
$\mathrm{T} 5(640 \mathrm{mg} / \mathrm{kg})$ & $83.6 \pm 0.8^{\mathrm{b}}$ & $16.4 \pm 0.8^{\mathrm{b}}$ \\
$\mathrm{T} 6(\mathrm{MT})^{*}$ & $91.2 \pm 0.5^{\mathrm{c}}$ & $8.8 \pm 0.5^{\mathrm{a}}$ \\
$\mathrm{T} 7(\mathrm{~T}) * *$ & $89.2 \pm 0.1^{\mathrm{c}}$ & $10.8 \pm .10^{\mathrm{a}}$ \\
\hline$* \mathrm{MT}=17$-a-methyltestosterone, $60 \mathrm{mg} / \mathrm{kg}$. \\
**T= Testosterone, $60 \mathrm{mg} / \mathrm{kg}$.
\end{tabular}

Growth performance, feed utilization and survival. Phase 1 feeding trial resulted in growth, feed intake, food conversion efficiency, and survival rate being statistically similar to the control group (Table 4). 
Table 4. Growth performance and survival of Clarias gariepinus larvae fed diets containing pine pollen in increasing levels, 17- $\alpha$-methyltestosterone, and testosterone for 72 days (First phase feeding).

\begin{tabular}{lcccccccc}
\hline & $I A B W(\mathrm{mg})$ & $F A B W(\mathrm{~g})$ & $W G(\mathrm{~g})$ & $F I$ & SGR (\%/day) & FCR & PER & $\%$ Survival \\
\hline T1(Control) & $0.004 \pm .0^{\mathrm{a}}$ & $1.45 \pm .10^{\mathrm{ab}}$ & $1.45 \pm .09^{\mathrm{ab}}$ & $1.58 \pm .16^{\mathrm{a}}$ & $8.36 \pm .10^{\mathrm{ab}}$ & $1.09 \pm .07^{\mathrm{a}}$ & $2.06 \pm .14^{\mathrm{a}}$ & $64.4 \pm 5.6^{\mathrm{a}}$ \\
$T 2(80 \mathrm{mg})$ & $0.004 \pm .0^{\mathrm{a}}$ & $1.49 \pm .03^{\mathrm{ab}}$ & $1.48 \pm .03^{\mathrm{ab}}$ & $1.66 \pm .02^{\mathrm{a}}$ & $8.40 \pm .03^{\mathrm{ab}}$ & $1.11 \pm .03^{\mathrm{a}}$ & $1.98 \pm .02^{\mathrm{a}}$ & $72.2 \pm 1.7^{\mathrm{a}}$ \\
$T 3(160 \mathrm{mg})$ & $0.004 \pm .0^{\mathrm{a}}$ & $1.59 \pm .13^{\mathrm{ab}}$ & $1.58 \pm .12^{\mathrm{ab}}$ & $1.96 \pm .07^{\mathrm{a}}$ & $8.49 \pm .11^{\mathrm{ab}}$ & $1.25 \pm .08^{\mathrm{a}}$ & $1.80 \pm .12^{\mathrm{a}}$ & $66.4 \pm 2.2^{\mathrm{a}}$ \\
$T 4(320 \mathrm{mg})$ & $0.004 \pm .0^{\mathrm{a}}$ & $1.61 \pm .11^{\mathrm{ab}}$ & $1.61 \pm .11^{\mathrm{ab}}$ & $1.97 \pm .11^{\mathrm{a}}$ & $8.51 \pm .09^{\mathrm{ab}}$ & $1.23 \pm .12^{\mathrm{a}}$ & $1.84 \pm .20^{\mathrm{a}}$ & $68.3 \pm 1.4^{\mathrm{a}}$ \\
$T 5(640 \mathrm{mg})$ & $0.004 \pm .0^{\mathrm{a}}$ & $1.73 \pm .15^{\mathrm{b}}$ & $1.73 \pm .15^{\mathrm{b}}$ & $2.10 \pm .07^{\mathrm{a}}$ & $8.61 \pm .12^{\mathrm{b}}$ & $1.23 \pm .06^{\mathrm{a}}$ & $1.82 \pm .09^{\mathrm{a}}$ & $66.2 \pm 6.4^{\mathrm{a}}$ \\
$T 6(M T)^{*}$ & $0.004 \pm .0^{\mathrm{a}}$ & $1.24 \pm .07^{\mathrm{a}}$ & $1.24 \pm .07^{\mathrm{a}}$ & $1.81 \pm .18^{\mathrm{a}}$ & $8.15 \pm .08^{\mathrm{a}}$ & $1.46 \pm .07^{\mathrm{a}}$ & $1.53 \pm .08^{\mathrm{a}}$ & $68.0 \pm 3.9^{\mathrm{a}}$ \\
$T 7(T)^{* *}$ & $0.004 \pm .0^{\mathrm{a}}$ & $1.51 \pm .01^{\mathrm{ab}}$ & $1.51 \pm .01^{\mathrm{ab}}$ & $1.84 \pm .11^{\mathrm{a}}$ & $8.43 \pm .01^{\mathrm{ab}}$ & $1.22 \pm .08^{\mathrm{a}}$ & $1.83 \pm .12^{\mathrm{a}}$ & $69.3 \pm 2.7^{\mathrm{a}}$ \\
\hline
\end{tabular}

IABW = initial average body weight $(\mathrm{g}) ; \mathrm{FABW}=$ final average body weight $(\mathrm{g})$; WG = weight gain $(\mathrm{g})$; FI = feed intake/fish; SGR = specific growth rate (\%/day); FCR = feed conversion rate; PER = protein efficiency ratio.

$* M T=17-\alpha$-methyltestosterone, $60 \mathrm{mg} / \mathrm{kg}$.

$* * \mathrm{~T}=$ Testosterone, $60 \mathrm{mg} / \mathrm{kg}$.

Values in the same column with different superscripts are significantly different $(P<0.05)$.

This suggests that the feed additives (i.e. pine pollen, 17- $\alpha$-methyltestosterone, and testosterone) did not have any effect on the larval catfish. The difference was only observed between the treatment of pine pollen at $640 \mathrm{mg} / \mathrm{kg}$ and the 17- $\alpha-$ methyltestosterone group $(P<0.05)$ but this difference was unclear since they were similar to the untreated group. Phase 2 feeding trial, conducted for another 45 days at a reduced density, revealed that the pine pollen groups (which are statistically similar to each other, P>0.05) enhanced the FABW, WG, FI, PER, and SGR, but not FCR $(P<0.05)$ of catfish compared with those of the control group (Table 5). 17- $\alpha$ methyltestosterone treatment significantly enhanced only the WG and SGR $(P<0.05)$ of catfish compared with the control group; however, the enhancement was significantly inferior $(P<0.05)$ to those of the pine pollen groups; testosterone did not have any effect on growth and food conversion efficiency of the catfish $(P>0.05)$. FI was significantly higher in the pine pollen groups which were statistically similar to each other, compared to either the control, 17- $\alpha$-methyltestosterone, and testosterone groups $(P<0.05)$; these three groups were statistically similar, implying that both steroid hormones did not have any effect on FI. All treatments had no effect on survival as rates were all statistically similar $(P>0.05)$.

Table 5. Growth performance and survival of Clarias gariepinus fry fed diets containing pine pollen in increasing levels, $17-\alpha$-methyltestosterone and testosterone after an additional of 45 days (second phase feeding).

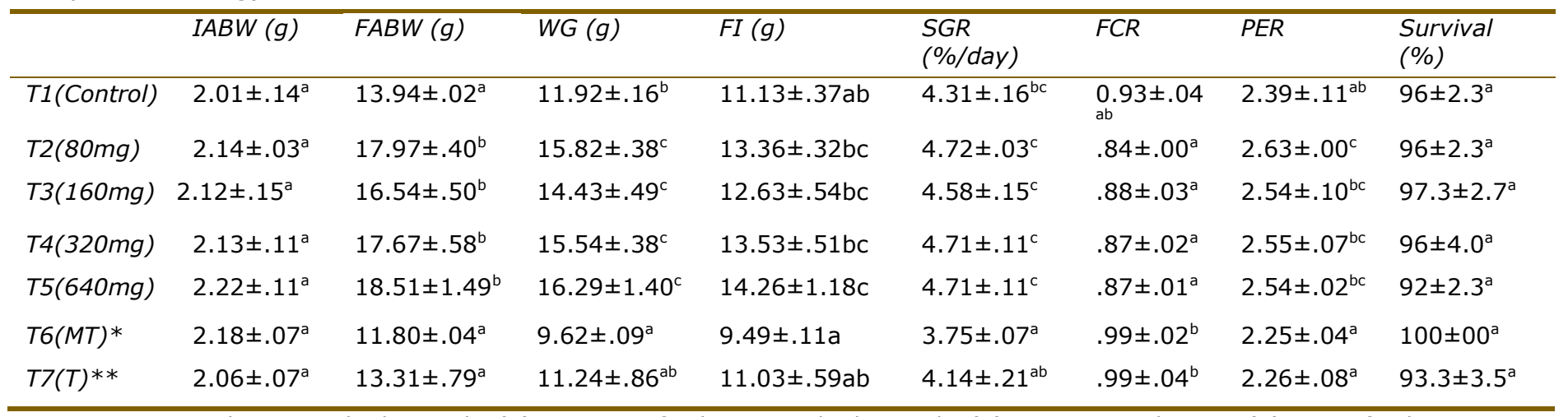

IABW = initial average body weight $(\mathrm{g}) ;$ FABW = final average body weight $(\mathrm{g}) ; \mathrm{WG}=$ weight gain $(\mathrm{g})$; FI = feed intake/fish; SGR = specific growth rate $(\% /$ day $) ; \mathrm{FCR}=$ feed conversion rate; $\mathrm{PER}=$ protein efficiency ratio.

$* 17$-methyltestosterone, $60 \mathrm{mg} / \mathrm{kg}$.

**Testosterone, $60 \mathrm{mg} / \mathrm{kg}$.

Values in the same column with different superscripts are significantly different $(P<0.05)$. 


\section{Discussion}

17- $\alpha$-Methyltestosterone, and testosterone, resulted in similar masculinization effects on the catfish $(92.1 \%$ and $89.2 \%$, respectively) despite the fact that testosterone is weakly androgenic (Piferrer et al, 1993). The dosage of 17- $\alpha-$ methyltestosterone used in the present study $(60 \mathrm{mg} / \mathrm{kg})$ did not result in paradoxical feminization. The present study demonstrated that $17-\alpha$-methyltestosterone at the dosage used was effective in the masculinization of Clarias gariepinus unlike in the channel catfish Ictalurus punctatus in which masculinization has not succeeded with any androgen tested to date although feminization is not a problem (Davis, 1990). In the Mediterranean Sea bass Dicentrarchus labrax, success in masculinization was achieved with dietary administration of $17-\alpha$-methyltestosterone at a lower dosage of $10 \mathrm{mg} / \mathrm{kg}$ initiated 126 days after fertilization and continued for 100 days (Blazques et al 1995). Timing of hormone administration in D. labrax might explain the result that in the present study sex differentiation was not observed at 72 days after hatching in all treatments, but only after 117 days from hatching. Timing in the administration of the androgens should possibly be at a later stage similar to $D$. Labrax.

Both 17- $\alpha$-methyltestosterone, and testosterone, resulted in significantly higher masculinization rates than did the pollen of Pinus tabulaeformis (average of $82.1 \%$ males). The rate for the two hormones were in agreement with findings in which Clarias gariepinus fed diets containing $50 \mathrm{mg} / \mathrm{kg}$ testosterone propionate resulted in $92.1 \%$ masculinization after 40 days (Alam \& Udin, 1998). In contrast, the lower rate of masculinization of the pine pollen group in the present study was similar to those of C. gariepinus fed diets containing $25 \mathrm{mg} / \mathrm{kg}$ or $100 \mathrm{mg} / \mathrm{kg}$ testosterone propionate (Alam \& Udin, 1998). The authors hypothesized that the lower male ratio at 100 $\mathrm{mg} / \mathrm{kg}$ was due to the antagonistic action of the hormone they used. The lower masculinization rate of catfish in the pine pollen groups in the present study might be due to the low phytosteroid content of the pollen of Pinus sp. The pollen of Pinus silvestris is reported to contain $80 \mathrm{ng} / \mathrm{g}$ of testosterone, $110 \mathrm{ng} / \mathrm{g}$ epitestosterone, and $590 \mathrm{ng} / \mathrm{g}$ androstenedione (SadenKrehula et al, 1971). The estimated total phytosteroid in the pine pollen in the present study was only $1.3 \%$ of that in either the $17-\alpha$-methyltestosterone or testosterone $(60 \mathrm{mg} / \mathrm{kg})$ groups and yet the difference in the rate of masculinization, although statistically significant, was only about $7-8 \%$. The choice of sex reversal agent by hatchery practitioners may not be based only on potency to affect the sex ratio but other factors such as consumer acceptability, cost of the androgen, shelf life, or a combination of these factors. Pine pollen serves as an alternative, if not a better choice, especially if its growth-promoting effect in the fry stage is considered.

The absence of apparent significant differences in the growth and feed efficiency between the control group, the pine pollen group, and the testosterone group after the first phase of feeding for 72 days showed that the hormones did not effectively influence these responses in the early stages of catfish development. This in contrast with the observation in the common carp Cyprinus carpio where feeding 17- $\alpha-$ methyltestosterone at $100 \mathrm{mg} / \mathrm{kg}$ retarded the growth of the fish (Lone \& Matty, 1980).

From larvae to fingerling stage (Phase 2 feeding trial), growth and food conversion efficiency of the pine pollen groups together were significantly higher than those of the hormone groups. It has been demonstrated that androgens stimulate growth by increasing food intake or increasing food conversion rate (Varadaraj \& Pandian, 1988). This could be the reason why the enhancement in both the FI and PER by pine pollen at all levels of supplementation was observed and were higher than the enhancement by either 17- $\alpha$-methyltestosterone, or testosterone; FCR was not enhanced at all. Administration of steroids by ingestion or injection in trout and carp stimulated incorporation of amino acids into proteins and protein deposition (Matty \& Lone, 1985). This could be the reason why PER was enhanced by dietary pine pollen. One hypothesis, that 17- $\alpha$-methyltestosterone induces growth by possibly acting in three different ways: (1) increased food conversion, (2) activation or secretion of other endogenous anabolic hormones, (3) direct effect on the gene expression in muscle 
cells, has been proposed (Lone \& Matty, 1980). This documented action of 17- $\alpha$ methyltestosterone was not observed in the present study.

To the best of our knowledge, this is the first study to compare the effects of phytosteroids as contained in the pine pollen with those of the steroid hormones 17- $\alpha$ methyltestosterone, and testosterone, on Clarias gariepinus. Various levels of androstenedione, a phytoandrogen, in Clarias gariepinus have been evaluated and their effects compared with that of a control diet containing no hormones (Turan \& Akyurt, 2005); they did not include 17- $\alpha$-methyltestosterone and testosterone as positive controls. In conclusion, pollen of Pinus tabulaeformis did not affect the growth, food conversion efficiency, and survival of Clarias gariepinus, when incorporated in the diet of catfish as early as 72 days after hatching. Its effects on growth performance and protein efficiency ratio could be elicited beyond 72 days. Growth enhancement was greater from dietary pine pollen than either from 17- $\alpha$-methyltestosterone, or testosterone; these two hormones only enhanced growth performance, but not feed intake or food conversion efficiency.

\section{Acknowledgements}

The authors are grateful to the Federal College of Fisheries \& Marine Technology P.M.B, Victoria Island, Lagos State, Nigeria for the partial support of the study of Mr. Issa Adenigba. They are also grateful to the Office of Vice Chancellor of Research and Extension of UP Visayas for the publication support.

\section{References}

Alam, M.S., Zamal Uddin, M. 1998. Effects of testosterone propionate on growth, survival and sex-ratio of African catfish (Clarias gariepinus Burchell). Bangladesh J. Fish. Res., 2(1): 31-39.

Christensen, M.S., 1981. A note on the breeding and growth rates of the catfish Clarias mossambicus in Kenya. Aquaculture 25: 285-288.

Davis, K.B., Simco, B.A., C.A. Goudie, C.A., Parker, N.C., Cauldwell, W., Snellgrove, R., 1990. Hormonal sex manipulation and evidence for female homogamety in channel catfish. Gen. Comp. Endocrinol., 78, 218-223.

Hunter, G. A., Donaldson, E.M., 1983. Hormonal sex control and its application. In: Fish physiology Vol XB (eds. W. S. Hoar, D. j. Randall and E. M. Donaldson). Academic Press. New York., pp. 223-303.

Jones, J. L., Roddick, J. G., 1988. Steroidal estrogens and androgens in relation to reproductive development in higher plants. J. Plant Physiol., 133:510-518.

Lee, K., Kim, A., Choi, E., 2009: Antioxidant and antiinflammatory activity of pine pollen extract in vitro. Phytotherapy Res. 23, 41-48.

Lee, K.H., Choi, E.M., 2009. Effect of pine pollen extract on experimental chronic arthritis. Phytotherapy Res., 23(5): 651-657.

Lone, K.P. and Matty, A.J. 1980. The effect of feeding methyltestosterone on the growth and body composition of common carp (Cyprinus carpio L.). Gen. Comp. Endocrinol., 49: 409-424.

Mao, G.X., Zheng, L.D., Cao, Y.B., Chen, Z.M., Lv, Y.D., Wang, Y.Z., Hu, X.L., Wang, G.F., Yan, J., 2012. Antiaging effect of pine pollen in human diploid fibroblasts and in a mouse model induced by D-galactose. Oxid Med Cell Longev 2012: 1-10.

Matty, A. J., Lone, K. P., 1985. Hormonal control of protein deposition. In: Cowey, C. B.; Mackie, A. M.; Bell, J. G., eds. Nutr. Feeding in Fish. Academic Press. pp. 147-167.

Nwadukwe, F.O., Ayinla, O.A., Abby-Kalio, N. J., 1993. Effect of various doses of Acetone-dried powdered Carp pituitary extract and season on hatchery propagation of Heterobranchus longifilis (Val.1840) (Pisces: Clariidae), J. Aqua. Trop. 8:33-40.

Pandian, T. J., Sheela, S. G., 1995. Hormonal induction of sex reversal in fish. Aquaculture, 138, 1-22.

Penman, D.J., 2016. Resource use efficiency in fish: Application of biotechnology in genetic improvement in tropical aquaculture. Institute of aquaculture, University of Stirling, Scotland Uk. https://www.slideshare.net/ExternalEvents. 
Piferrer, F., Baker, I.J., Donaldson, E.M., 1993. Effects of natural, synthetic, aromatizable, and nonaromatizable androgens in inducing male sex differentiation in genotypic female chinook salmon (Oncorhynchus tshawytscha). Gen. Comp. Endocrinol. 91(1): 59-65.

Sadden Krehula, M., Tajic, M, Kolbah, D., 1971. Testosterone, epitestosterone and androstenedione in the pollen of Scotch pine P. Silvestris L. Experientia 27(1): 108109.

SaddenKrehula, M., Tajic, M, Kolbah, D., 1979. Sex hormones and corticosteroids in pollen of Pinus nigra. Phytochem., 18(2): 345-346.

Turan, F., Akyurt, I., 2005. Effects of red clover extract on growth performance and body composition of African catfish Clarias gariepinus: Fish. Sci., 71: 618-620.

Varadaraj, K.; Pandian, T. J., 1988. Food consumption and growth efficiency of normal and phenotypic male Oreochromis mossambicus. In Pullin, R. S. V.; Bhukaswan, T.; Tonguthai, K.; Maclean, J. L., eds. The Second International Symposium on Tilapia in Aquaculture. ICLARM, Manille. Conference Proccdings. 15: $429-432$.

Viveen, W.J.A.R, Richter, C.J.J., Van-Ordt, P.G., Janseen, J.A.L., Huisman, E.A., 1985. Practical Manual for the culture of the African Catfish (Clarias gariepinus). Section for Research and Technology, Box 20061, 5600 EB. The Hague, The Netherlands, Pages: 121.

Zhong-han, Y., Yin, T., Zong-xun, C., Tsao, T.H., 1994. The changes of steroidal sex hormone - testosterone contents in reproductive organs of Lilium davidii Duch. Acta Bot Sin 36: 215-220. 